\title{
The Relationship of Interest Rate, Exchange Rate, GDP and FDI with Respect to Chinese Economy
}

\author{
K.Vidhya, S.B.Inayath Ahamed
}

\begin{abstract}
Economic growth can be described as the boom in purchasing power of a country in offering the economic goals of its population. China is the major emerging market in Asia. Late 1970's China has gone through major economic reform, which leads them to the fastest developing country in the world. In this article, the Analyzer attempted to become aware of the impact of FDI, Real Interest Rate, Exchange rates and Gross Domestic Product (GDP) with respect to each other. Chinese GDP is greater than $10 \%$ over 30 years constantly. The researcher attempted to find the scope of the future boom of China and the global economic system, taken into consideration the current financial slowdown of China, the new economic interdependence between China and its trading partners created a variety of problems and so raised many issues that require further study the future of Chinese economy, also studied the china's success story by comparing FDI, real interest rate, exchange rates and Gross Domestic Product for different developing countries to drive their economies by means of following Chinese model.
\end{abstract}

\section{Keywords: FDI, Interest rates, Exchange rates GDP}

\section{INTRODUCTION}

China is one of the positive examples of the impact of an open economy to the global. In 1978 china undergone major economic policy reform which attracted the foreign player to invest in China and lead to the world second largest economy. The same way India also followed the footprints of China that open its economy in 1991 which helped to position itself as world third-largest economy. Both the countries believe that the policy adoption only helped the nation to achieve its economic goals.

In the course of recent years, the Chinese financial structure had bragged normal boom of $10 \%$ with highest of $13 \%$. As a result of this exceptional growth, China has developed into the second greatest economy on the world and also the biggest consumer of Raw materials; when the second biggest economy starts to give indications of weakness, this has an overflow control on the worldwide economy. China's slowdown has driven the nation to allow its forex to exchange further freely, provoking a decrease in commodity expenses and trading competitors to cheapen their own forex. This, growth decline, has summoned a cover of doubt among U.S. traders.

Revised Manuscript Received on September 10, 2019.

K.Vidhya, Research scholar, Department of Business Administration, Kalasalingam Academy of Research and Education, Srivilliputhur, Tamil Nadu, India.

(E-mail: kkvidhyamba@gmail.com)

Dr.S.B.Inayath Ahamed, Assistant Professor, Department of Business Administration, Kalasalingam Academy of Research and Education, Srivilliputhur, Tamil Nadu, India.

(E-mail: inayathashamed@gmail.com)
But whereas the Short-Term External Debt of China is under control when compared with other emerging economies (i.e.,) how a lot of cash China needs to pay back to outsiders. It's just $10 \%$ versus about $19 \%$ for other developing markets. Additionally, Inbound Portfolio Investment is the greatest burden for present moment, and lead to big currency volatility. On that measure, China has a minimum of $3 \%$ with respect to $16 \%$ of the average of other Emerging economies. Dollar-Denominated Debt is just about $35 \%$ where as $100 \%$ for the average of other developing economies.

Recently Chinese Yuan added into SDR by IMF which added further value to its home currency. But there is a need to study about future movements of the Chinese economy. Since there is the economic slowdown in 2015 than the expected, which is the biggest fear for the world economy and its trading partners recent slowdown created a variety of problems and so raised many issues that require further study the future of Chinese economy.

\section{RESEARCH OBJECTIVES}

This research is aimed

- To understand the association among exchange rate, Interest rate, Foreign Direct Investment, and GDP.

- $\quad$ To find the impact of each variable.

- What India and other developing countries can absorb from China.

\section{THEORY AND HYPOTHESIS}

\subsection{Real Interest Rate:}

In the principle of economy, the interest rate can be depicted as a value that is picked up in the exertion of a value that has been contributed. A actual interest rate is an interest rate that has been changed in accordance with evacuates the impacts of inflation to replicate the actual cost of funds to the borrower and the actual earning to an investor. The actual interest rate on a investment is determined as the nominal interest rate is higher than the inflation rate.

Real Interest Rate $=$ Nominal Interest Rate - Actual Inflation

These rates will replicate the association between trades of currency (Patterson dan Lygnerud, 1999). There are long term and short term rates as indicated by Patterson dan Lygnerud (1999). Short term rates are affected by the Central Bank intervention; subsequently currency is being 
monopolized applicably. In long term currency value,demonstrates the state of the present economy and the likelihood of inflation. Both long term as well as short term currency rates are connected and work with each other. As indicated by Certified Public Accountant (CPA) Australia there are two different ways of estimating the risks of interest rates, they are re pricing profiles and sensitivity analysis.

\subsection{Foreign Direct Investment:}

Foreign Direct Investment (FDI) has been seen as a improvement to financial growth in developing nations. Its capacity to manage two noteworthy impediments; to be specific, deficiencies of financial resources and innovation and capacities, has made it the principal point of consideration for policymakers in low-income nations specifically.It can affect the host economy through an group of channels.Basically, it causes by adding to the assets accessible for investment and capital creation. The exchange of knowledge, aptitudes, imaginative capability, and authoritative and administrative practices between nations is likewise upgraded through the exercises of foreign direct investors.In fact, foreign direct investment inflows remain a significant indicator that aides the course and direction of the improvement and usage of monetary arrangements and strategies of governments in these areas. It is likewise basic learning that foreign direct investment inflows give gravely required capital supply to fund local exercises making the stage for the exchange of innovation and technology for the host nation. There is no uncertainty that these components are vital requirements that can establish the framework for the incorporation of forming economies into the worldwide economy as a feature of the general drive towards financial development.

\subsection{Exchange Rate}

Foreign exchange rate is a worth that a currency has associated to another currency (Krugman, 2001). Tiwari (2003) indicated that exchange rate can be divided into two types, fixed exchange rate and variable exchange rate. In a fixed exchange rate, it is set by the governing body, however variable exchange rate is set by the market with or without the influence of the governing body in the effort to stabilize the monetary (Kuncoro, 2001).

\subsection{Gross Domestic Product (GDP)}

GDP is a important indicator of a nation's microeconomic situation and development (Haggart, 2000). GDP can be viewed from two kinds such as the expenditure approach and the income approach. The expenditure approach takes account of all goods and services within a specified time period. For an example, household items that we used to buy regularly, consumptions from a foreign investor and services (Andolfatto, 2005).The income approach can be termed as the level of worker's compensation, rent, interest rates, the income of a particular business, the tax of a manufactured goods and import level (McConnel and Brue, 2008).

\section{RESEARCH HYPOTHESIS \& RESULTS}

$\mathrm{H}_{0}$ : FDI is not driven by Real Interest Rate, GDP and Exchange Rate
$\mathrm{H}_{1}$ : GDP is influenced by FDI, Real Interest Rate, and exchange rate

$\mathrm{H}_{2}$ : Real Interest Rate has an effect of GDP

$\mathrm{H}_{3}$ : Foreign Direct Investment has an effect of GDP

$\mathrm{H}_{4}$ : Exchange Rate has an effect of GDP

$\mathrm{H}_{5}$ : Real Interest Rate has an effect of FDI

$\mathrm{H}_{6}$ : Real Interest Rate has an effect on Exchange Rate

$\mathrm{H}_{7}$ : Exchange Rate has an effect of FDI

\section{RESEARCH METHODS}

\subsection{Types of Research}

The methodology of the research for this study is a Descriptive study. Quantitative methods are created based on the available quantitative information and associated with the statistical analysis.

\subsection{Data Collection Techniques}

The data used in this study are the secondary data which is collected from World Bank data sources.

\subsection{Methods of Data Analysis}

Econometrics analysis: Linear and Multiple Regression analysis, Correlation test, Co-integration, Granger casualty and Impulse analysis.

\section{RESULTS AND DISCUSSION}

\subsection{Multiple Regression analysis}

Regression analysis For Foreign Direct Investment

\begin{tabular}{|c|c|c|c|c|c|}
\hline $\begin{array}{l}\text { Regress } \\
\text { ion }\end{array}$ & R Square & $\begin{array}{l}\text { Adjusted } \\
\text { R Square }\end{array}$ & $F$ & $\begin{array}{l}p \text { - } \\
\text { valu } \\
e\end{array}$ & sig \\
\hline FDI & $\begin{array}{l}0.845773 \\
457\end{array}$ & $\begin{array}{l}0.831314 \\
718\end{array}$ & $\begin{array}{l}58.49566 \\
065\end{array}$ & $\begin{array}{l}0.00 \\
00\end{array}$ & $\begin{array}{l}\text { Ye } \\
\text { s }\end{array}$ \\
\hline $\begin{array}{l}\text { Exchan } \\
\text { ge Rate }\end{array}$ & $\begin{array}{l}0.826498 \\
293\end{array}$ & $\begin{array}{l}0.810232 \\
508\end{array}$ & $\begin{array}{l}50.81207 \\
512\end{array}$ & $\begin{array}{l}0.00 \\
00\end{array}$ & $\begin{array}{l}\text { Ye } \\
\text { s }\end{array}$ \\
\hline GDP & $\begin{array}{l}0.327146 \\
952\end{array}$ & $\begin{array}{l}0.264066 \\
979\end{array}$ & $\begin{array}{l}5.186225 \\
291\end{array}$ & 0.49 & $\begin{array}{l}\text { Ye } \\
\text { s }\end{array}$ \\
\hline
\end{tabular}

Foreign Direct Investment is a source of economic growth of developing countries in $21 \mathrm{st}$ century. After the liberalization, China is the country who attracted more FDI in the world from 1980 onwards. The above table clearly demonstrates that Real Interest Rate, Currency Value, and GDP are factors which attract the foreign players to invest in the host country. These three factors are determining FDI $85 \%$ since the $\mathrm{R} 2$ value is 0.846 . Where $\mathrm{P}$-value is significant with $95 \%$ confidence. Since $F$ value is 58.5 which is greater than 2.93 the above model fitness is perfect. So we reject the null hypothesis $(\mathrm{H} 0)$. 


\begin{tabular}{|l|l|l|l|l|}
\hline & $\begin{array}{l}\text { Exchange } \\
\text { Rate }\end{array}$ & FDI & GDP & $\begin{array}{l}\text { Real } \\
\text { Interest } \\
\text { Rate }\end{array}$ \\
\hline Currency & 1 & & & \\
\hline FDI & 0.877234 & 1 & & \\
\hline GDP & 0.079619 & 0.301045 & 1 & \\
\hline $\begin{array}{l}\text { Real } \\
\text { Interest } \\
\text { Rate }\end{array}$ & -0.052725 & -0.292274 & -0.506506 & 1 \\
\hline
\end{tabular}

Correlation of exchange rate and FDI are strongly positive. That is whenever the inflow of FDI increases the value of Chinese Yuan increases against US Dollar.The real Interest rate has an inverse relationship with FDI and GDP.Which means when there are high FDI inflow Real interest rate decreases. Which means that high FDI leads to higher inflation.fdi is $30 \%$ account for domestic inflation.

Impulse Analysis of one standard deviation:

Significant level $* \mathbf{P}<\mathbf{0 . 0 5}$

Table:2
Response to Cholesky One S.D. Innovations \pm 2 S.E.
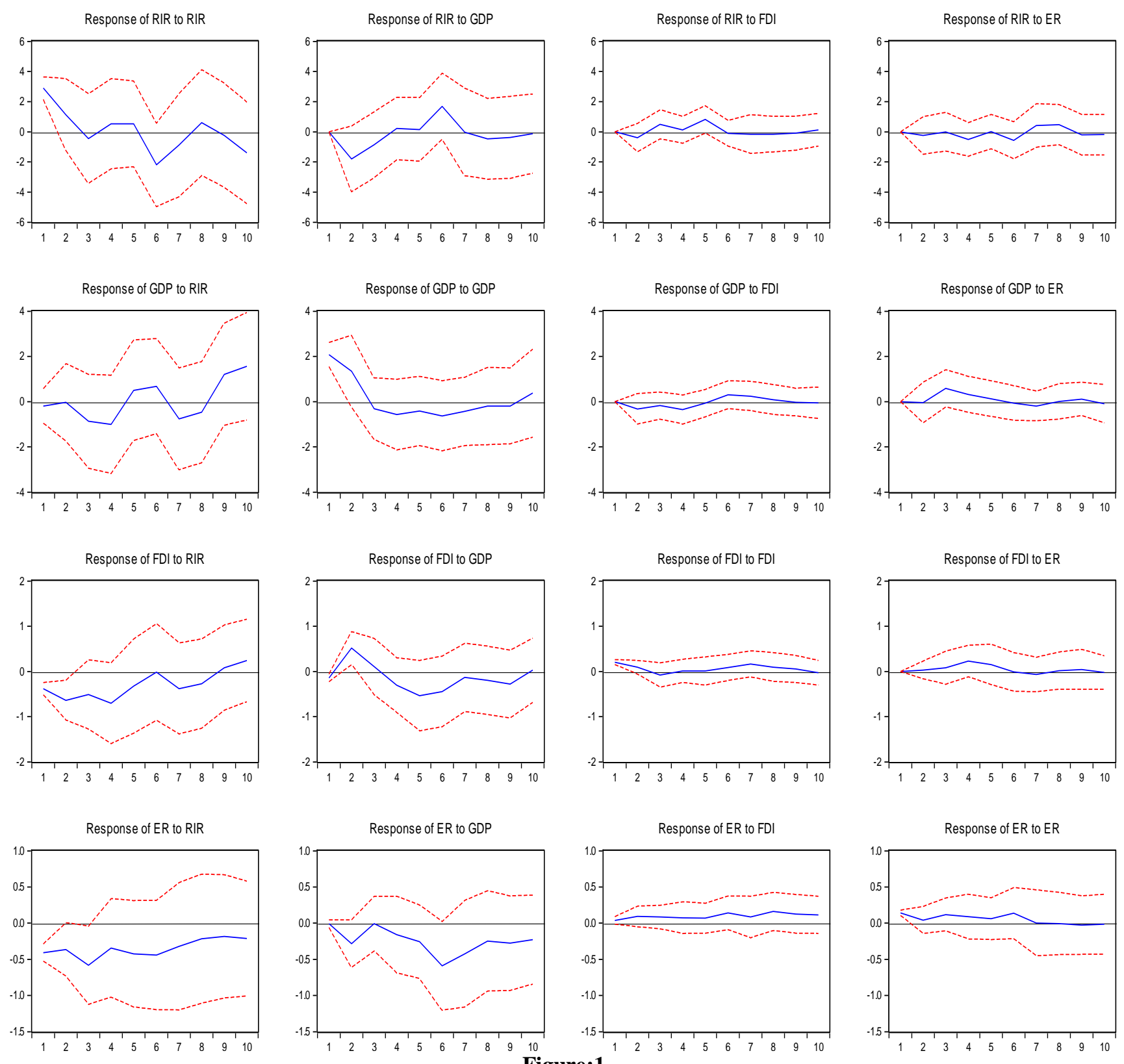

Figure: 1 
The above figure 1 is the result of impulse analysis of standard deviation one.

Though these four factors are independent in nature because of the globalization all these are dependent one another. The above picture clearly explains that when there is a shock in FDI the response of Real interest rate goes negative in the beginning later moves closer to zero .same way GDP continues negative for four years later start to move in an uptrend. The exchange rate in the positive trend.
From this result, it can understand that any changes in FDI will not impact Chinese economy for a longer period since the economy is not depending on the external factors alone. We reject the hypothesis $\mathrm{H}_{3}$.

When there is a shock in Real Interest Rate, the response of FDI is in negative, RIR impacts FDI means that higher the RIR leads to higher the FDI inflow.

Granger Casualty Test:

Lag 4

\begin{tabular}{|l|l|l|l|l|l|}
\hline Null Hypothesis: & F-Statistic & Prob. & Direction & Relationship & $\begin{array}{l}\text { Acceptance of } \\
\text { the } \\
\text { Hypothesis }\end{array}$ \\
\hline FDI does not Granger Cause ER & 4.48003 & $0.008^{*}$ & $\begin{array}{l}\text { Uni } \\
\text { Direction }\end{array}$ & Casualty Exist & Reject Null \\
\hline ER does not Granger Cause FDI & 2.31911 & 0.0874 & No & No Casualty & Accept Null \\
\hline GDP does not Granger Cause ER & 3.04432 & $0.0376^{*}$ & $\begin{array}{l}\text { Uni } \\
\text { Direction }\end{array}$ & Casualty Exist & Reject Null \\
\hline ER does not Granger Cause GDP & 0.47723 & 0.7521 & No & No Casualty & Accept Null \\
\hline RIR does not Granger Cause ER & 0.31637 & 0.8641 & No & No Casualty & Accept Null \\
\hline ER does not Granger Cause RIR & 0.31031 & 0.8681 & No & No Casualty & Accept Null \\
\hline GDP does not Granger Cause FDI & 2.10585 & 0.1128 & No & No Casualty & Accept Null \\
\hline FDI does not Granger Cause GDP & 0.31757 & 0.8633 & No & No Casualty & Accept Null \\
\hline RIR does not Granger Cause FDI & 0.55744 & 0.6957 & No & No Casualty & Accept Null \\
\hline FDI does not Granger Cause RIR & 3.02758 & $0.0383^{*}$ & $\begin{array}{c}\text { Uni } \\
\text { Direction }\end{array}$ & Casualty Exist & Reject Null \\
\hline RIR does not Granger Cause GDP & 1.3426 & 0.2844 & No & No Casualty & Accept Null \\
\hline GDP does not Granger Cause RIR & 5.49169 & $0.003^{*}$ & $\begin{array}{c}\text { Uni } \\
\text { Direction }\end{array}$ & Casualty Exist & Reject Null \\
\hline
\end{tabular}

Significant level $* \mathbf{P}<0.05$

Table : 3

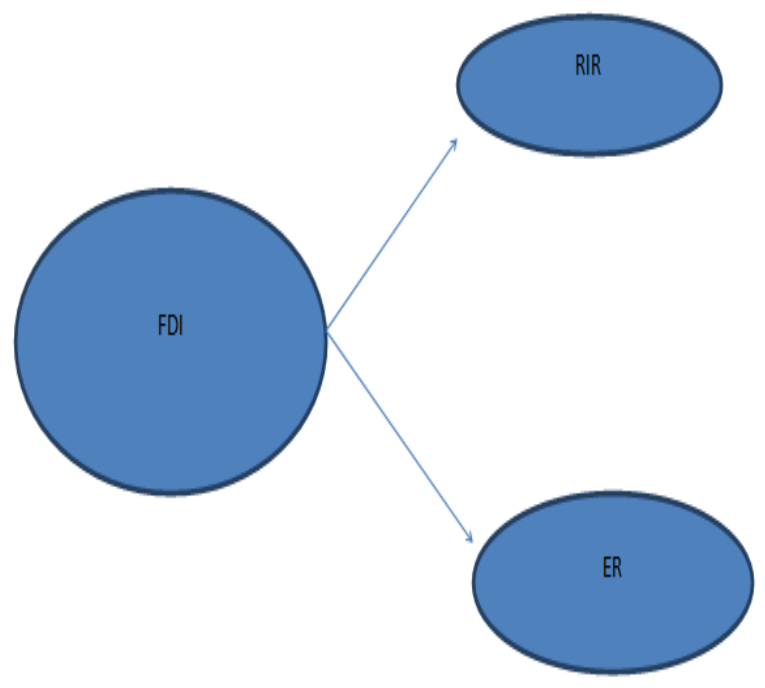

Figure: 2

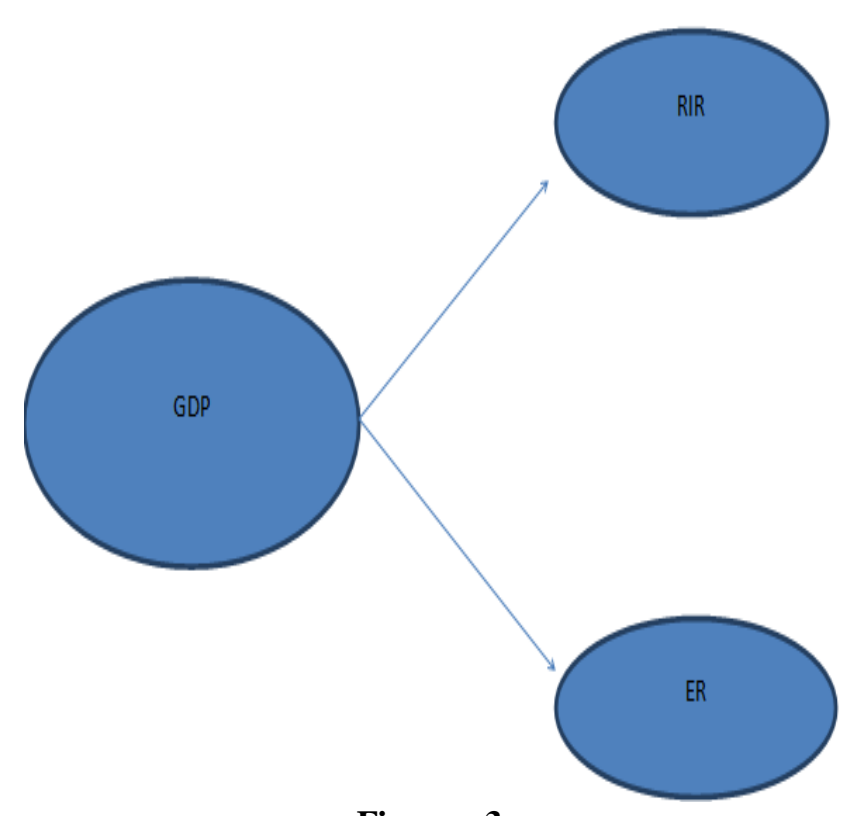

Figure : 3 
From the above table and figure, we can come to a conclusion that FDI and GDP are the cause of the changes in RIR and ER.It might be the policymaker decision might cause the RIR but based on the FDI inflow and GDP only the policymakers. In the case of China FDI will not affect GDP (refer impulse analysis) since it will not affect RIR and ER immediately. China is the country where GDP is not completely depending FDI since it has sufficient capital. Since we accept the null hypothesis of $\mathrm{H}_{2}, \mathrm{H} 3, \mathrm{H}_{4}, \mathrm{H} 5, \mathrm{H} 6$, and $\mathrm{H}_{7}$.

\section{CONCLUSION AND RECOMMENDATIONS}

The growth in the China's share of global trade and financial transactions has had a major control on the world economy in common and on the US economy in specific. From the above analysis, we can conclude that Chinese economy is not only driven by foreign Investment also by its public fund as well. In future, any shock in FDI will not impact the growth of China for a longer period whereas the economy will further get stronger than earlier because of its currency reserves and low external debt. Moreover Chinese economy is the major economy which drives the US economy, any shortfall in China will directly impact US economy. Because China is a major investor in US debt market. The bond between world economy and Chinese economy stronger than ever before. Any shock might impact the world economy like 2008 subprime crisis in future. But Chinese economy will not get affected deeper because of its independence in capital rising. China is the country who utilized the globalization to boost its economy.

\section{REFERENCES}

1 Naughton, B. (2007). The Chinese economy: Transitions and growth. MIT press.

2 Naughton, B. (2007). Transitions and Growth. Cambridge: Massachusetts Institute Of Technology Press, 20007, 528.

3 Huang, Y. (2008). Capitalism with Chinese characteristics: Entrepreneurship and the state. Cambridge University Press.

4 Li, J. (2007). Development and Tax Policy: Case Study of China.

5 J.Peter Leo Deepak, R.Amudha "Impact of Forex Swap Among BRICS:Post Global Financial Crisis, Jour of Adv Research in Dynamical \& Control System,07-Special Issue,July 2017'Special Issue on Management studies.

6 Demurger, S. (2001). Infrastructure development and economic growth: an explanation for regional disparities in China?. Journal of Comparative Economics, 29(1), 95117.

7 Barnett, A. D. (1981). China's economy in global perspective ( $\mathrm{p}$. 522). Washington, DC: Brookings Institution.

8 Chai, J. C. (1998). China: Transition to a Market Economy. OUP Catalogue.

9 www.worldbank.org

10 www.pbc.gov.cn 